Article

\title{
Perspectives on Sustainable Resource Conservation in Community Nature Reserves: A Case Study from Senegal
}

\author{
Liliana Pacheco $^{1,2}$, Sara Fraixedas ${ }^{3, *}$, Álvaro Fernández-Llamazares ${ }^{1,3}$, Neus Estela ${ }^{1,2}$, \\ Robert Mominee ${ }^{4}$ and Ferran Guallar ${ }^{1,2}$
}

1 Instituto Jane Goodall España (IJGE), Zoo de Barcelona, Parc de la Ciutadella, s/n, 08003 Barcelona, Spain; E-Mails: liliana@janegoodall.es (L.P.); alvaro@janegoodall.es (A.-F.L.); neus@janegoodall.es (N.E.); ferran@janegoodall.es (F.G.)

2 Réserve Naturelle Communautaire de Dindéfélo (RNCD), Dindéfélo, Kédougou, Senegal

3 Institut de Ciència i Tecnologia Ambientals (ICTA), Edifici C, Facultat de Ciències, Campus de Bellaterra, Universitat Autònoma de Barcelona (UAB), 08193, Bellaterra (Cerdanyola del Vallès), Spain

4 Peace Corps Senegal, B.P. 37, Kédougou (town), Lawol Bandafassi (road to Bandafassi), Senegal; E-Mail: rmominee@gmail.com

* Author to whom correspondence should be addressed; E-Mail: Sara.Fraixedas@e-campus.uab.cat; Tel.: +34-935-812-974; Fax: +34-935-813-331.

Received: 23 August 2012; in revised form: 5 November 2012 / Accepted: 6 November 2012 / Published: 16 November 2012

\begin{abstract}
The coalescing of development and conservation has recently given rise to community-based conservation. Under this framework, sustainable livelihood strategies are incorporated into conservation goals on the basis that the integration of local priorities into management guidelines benefits rather than impedes conservation efforts. Consistent with this approach, the Community Nature Reserve of Dindéfélo in Kédougou, Senegal endeavors to protect biodiversity without jeopardizing local people's reliance on natural resources. In this article we provide evidence that sustainable resource conservation is a very powerful mechanism in redirecting labor and capital away from ecosystem-degrading activities. To do this, we present three examples of projects, aiming to illustrate different ways in which local people's management and sustainable use of natural resources can be beneficial in terms of biodiversity conservation, socioeconomic development, and human well-being.
\end{abstract}


Keywords: sustainable development; conservation strategies; community conservation; nature reserve; Senegal

\section{The Erosion of Biodiversity: Drivers and Concerns}

Biodiversity erosion is currently recognized as one of the burning topics of study in the recent scientific literature [1-3]. Since the 1970s, much research has addressed the issue with particular emphasis on attempting to estimate the percentage of global biodiversity threatened with extinction [4-6]. The most commonly cited figure shows that up to $38 \%$ of the world's total number of species could be threatened with extinction [7], although it is widely recognized that this appraisal is a serious underestimation, taking into account that biodiversity in many parts of the world, especially in tropical latitudes, remains poorly studied and that the conservation status of only $2.7 \%$ of the world's described biodiversity is currently known [7,8].

Indeed, the goal of biodiversity conservation faces the complex tasks of: (1) identifying the existing information on the ecology of species; (2) evaluating their respective causes of endangerment and threats; and (3) establishing a conservation framework to confront their endangerment. Extensive biological research is required for the implementation of conservation strategies and the establishment of a protection framework for biodiversity. Until now, most of the efforts to conserve biodiversity have come from conservationists aware of the current degradation rates of the world's ecosystems. However, in the last two decades some attempts have been made to try to account for local people's perspectives and perceptions towards biodiversity $[9,10]$.

For most rural and indigenous people living in natural environments, forest resources are the basis of their livelihoods, providing a wide variety of products including food, medicine, timber or charcoal, and material for building and crafting [11,12]. Moreover, according to the World Health Organization, up to $80 \%$ of the world's population relies to some extent on forest resources such as medicinal plants for curing various diseases [13], and, at the same time, these resources have an intangible spiritual value $[14,15]$. Numerous studies have also revealed the importance of wild vegetal species in human nutrition-particularly in Africa [16-18], many of which may be endangered [19-21]. It is therefore crucial to ascertain local people's reliance on biodiversity as a first step towards sustainable resource conservation. This is due to two assumptions: (1) people's well-being in many parts of the world is highly dependent on wild resources; and (2) local people have an important role in the success of biological conservation strategies.

\section{Community Conservation and Sustainable Development}

In general terms, there are two perceptions of the effects that local people's management and use of natural resources have in terms of biodiversity conservation. On the one hand, some authors note that local people's use of resources may lead to overexploitation, particularly in those cases in which there is a regime of commercialization [22-24]. This framework provides theoretical justification for the conservationist paradigm of strict natural protection (e.g. National Parks), where any prospection or use of natural resources is forbidden. On the other hand, many studies argue that locals people's 
management actually enhances biodiversity [25-27], since local knowledge-based management strategies ensure a simultaneously focus on landscapes and species, while at the same time specialization is avoided [28,29]. Under this framework, initiatives allowing people to live in Community Nature Reserves to make a sustainable use of natural resources have been developed on the basis that the incorporation of local priorities into management guidelines benefits conservation goals [30-32]. However, as many authors hold [33,34], both views are not strictly opposed, but rather complementary or even case specific.

The merging of development and conservation has given rise in the past few years to community-based natural resource management. Community conservation attempts to create a link between development and conservation [35,36], so that both may be achieved simultaneously. In this context, sustainability emerges as a mechanism to: (1) redirect labor and capital away from activities that degrade ecosystems; (2) encourage commercial activities supplying ecosystem services as joint outputs; and (3) raise incomes to reduce dependence on unsustainable resource extraction. In this sense, sustainable livelihood strategies are incorporated as substitutes to ecosystem-degrading activities [37]. This may help to close the gap between conservation managers and local communities [38,39].

This community-based approach has gained particular attention in the international conservation arena, particularly in the sharp debate about the role of conservation in poverty reduction $[33,34,40]$. Disentangling the existing link between biodiversity conservation and poverty alleviation is an important element of research in the field of conservation policy [41,42], especially in Africa where: (1) historically, the costs of biodiversity conservation have not been distributed in proportion to their benefits, and in many cases have been paid by local people [43-46]; and (2) there is urgent need of poverty reduction [41]. Nowadays it is widely accepted that biodiversity crisis and poverty are related problems that should be tackled together. However, clear conceptual frameworks are highly required if policies in these two realms are expected to be combined [33]. In the present article it is held that poverty reduction depends strongly on natural resource conservation. This position converges with the approach of community-based conservation, since strictly protected areas are unlikely to achieve poverty reduction goals $[46,47]$.

The purpose of this paper is to examine different ways in which a coalescing between development and conservation can be achieved in the Community Nature Reserve of Dindéfélo in Kédougou, Senegal.

\section{The Community Nature Reserve of Dindéfélo-A Study Case}

\subsection{Context, Data and Forest Profile}

Senegal represents an ideal country in which to address the questions raised previously. Although approximately $57.9 \%$ of Senegal's population lives in rural areas where forest resources are central to their livelihood [48], conservation projects including local people in their design and implementation are still rare. Therefore, there lacks a clear understanding of the local populations' resource use and attitudes, factors which are essential for the success of conservation projects aiming to promote sustainable development $[49,50]$. 
In terms of legal status, only approximately $11 \%$ of Senegal's total land is under some form of protection [51]. These protection figures include both natural areas managed solely under protection objectives and nature reserves managed by local communities, such as the Community Nature Reserve of Dindéfélo, the case study of the current article.

The Community Nature Reserve of Dindéfélo (Réserve Naturelle Communautaire de Dindéfélo, henceforth RNCD) was created by the Rural Council of Dindéfélo in 2010 and is located in the Kédougou Department, in the south-eastern extreme of Senegal (Figure 1). It is not only home to a great diversity of flora and fauna, but also to great cultural variety with three ethnic groups (mainly Fula, but also Bassari and Diakhanké) spread over 10 villages and hamlets in and around the RNCD, giving a total sum of 6951 inhabitants and 651 households. Nevertheless, the RNCD program is located on mostly Fula territory. Fula were known for their nomadic behavior, but in the last 50 years they have settled in different parts of West Africa, becoming the most numerous ethnic group without a country. Their traditional agricultural methods remain little productive and even dangerous - when slopes are used to cultivate - and tend to extend their fields causing forest deforestation. They are also the most prominent traders (small-scale) and shoppers of the subregion comprised from Mauritania to Nigeria [52].

The RNCD covers an area of 13,300 ha-more than half of the total area of the Rural Community - and it is located at the edge of two different eco-regions: the Western Sudan savannah and the Guinean forested mosaic (eco-regions AT0707 and AT0722, respectively), according to the classification by Olson et al. [53]. Five types of vegetation predominate in the study area: (1) woodland, shrub and herbaceous savannah; (2) woodland; (3) dense forest; (4) gallery forest; and (5) bowé, outcrops of laterite rock where trees and shrubs cannot grow and that are only covered by grass during the rainy season. Land use and vegetation distribution and percentages in the RNCD are shown in Table 1 and Figure 2.

The production system of local people is agropastoral with the primary productive activities being agriculture, animal husbandry, and vegetable gardening. Agriculture is universally practiced amongst the populace, with cereal grain production leading cash crops. Secondary productive activities include the exploitation of forestry products, the transformation of agricultural commodities for local consumption, petty commerce, fishing, artisan crafts, and some traditional gold mining [54].

Table 1. Distribution of land use in the Réserve Naturelle Communautaire de Dindéfélo (RNCD).

\begin{tabular}{ccc}
\hline Type of land use & Surface Area (ha) & Surface Area Percentage \\
\hline Woodland and herbaceous savannah & 4860 & $37 \%$ \\
Forests (all types) & 3197 & $24 \%$ \\
Shrub savannah & 2430 & $18 \%$ \\
Bowé and prairie grass & 2174 & $16 \%$ \\
Agricultural areas & 512 & $4 \%$ \\
Others (houses, rocks,...) & 128 & $1 \%$ \\
\hline TOTAL & $\mathbf{1 3 . 3 0 1}$ & $\mathbf{1 0 0 \%}$ \\
\hline
\end{tabular}


Figure 1. (a) Rural Community of Dindéfélo (Communauté Rural, CR de Dinféfélo) in the Kédougou Department, in the south-eastern extreme of Senegal. (b) Location of the RNCD within the Rural Community: internal zoning map in accordance with the vulnerability criteria related to chimpanzees (Zone $1=$ high level of protection; Zone 2 = medium level of protection; Zone 3 = low level of protection).

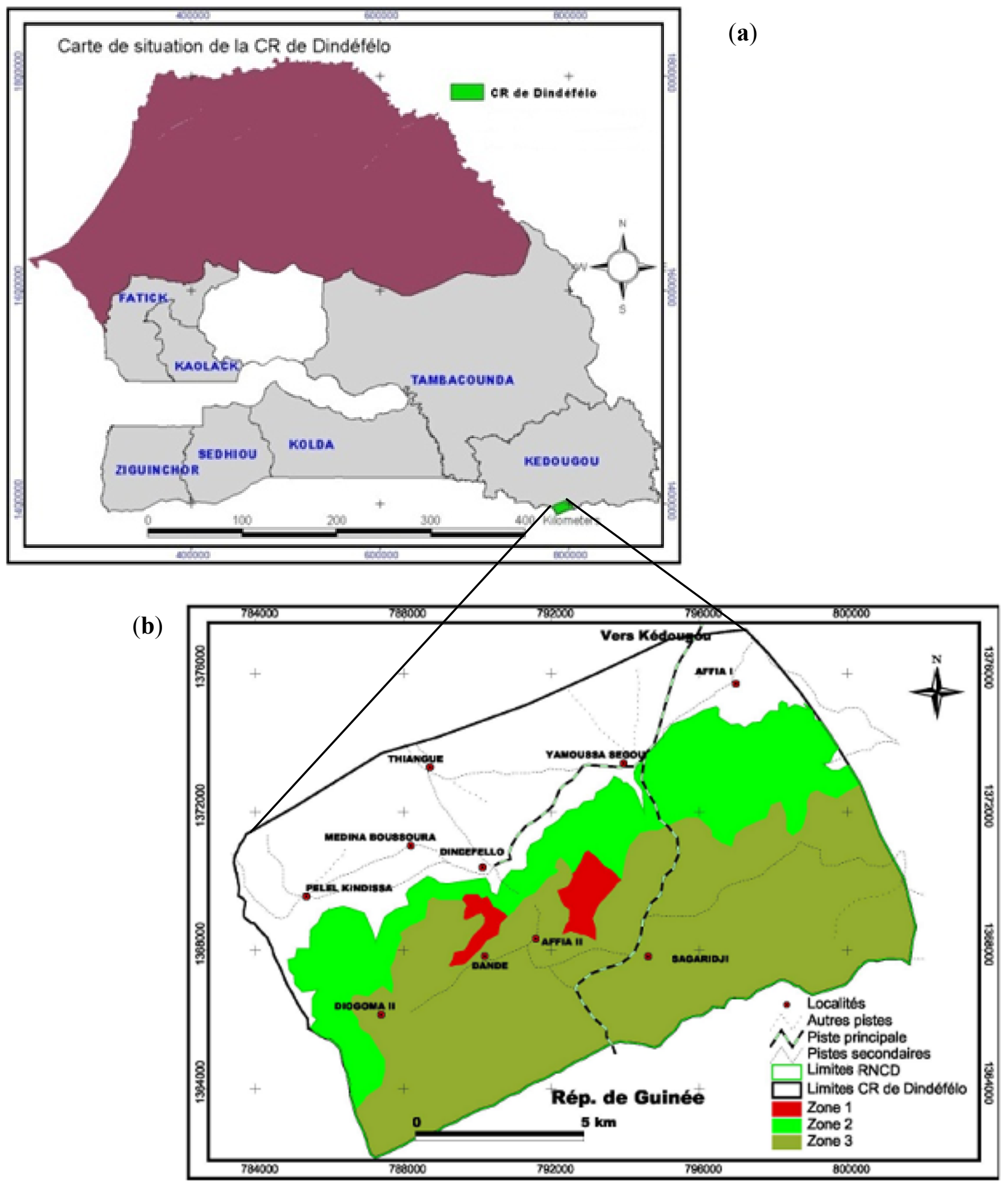

Source: Management plan of the RNCD 2012-2016, USAID/Wula Nafaa program [55]. 
Figure 2. Land use distribution in the RNCD.

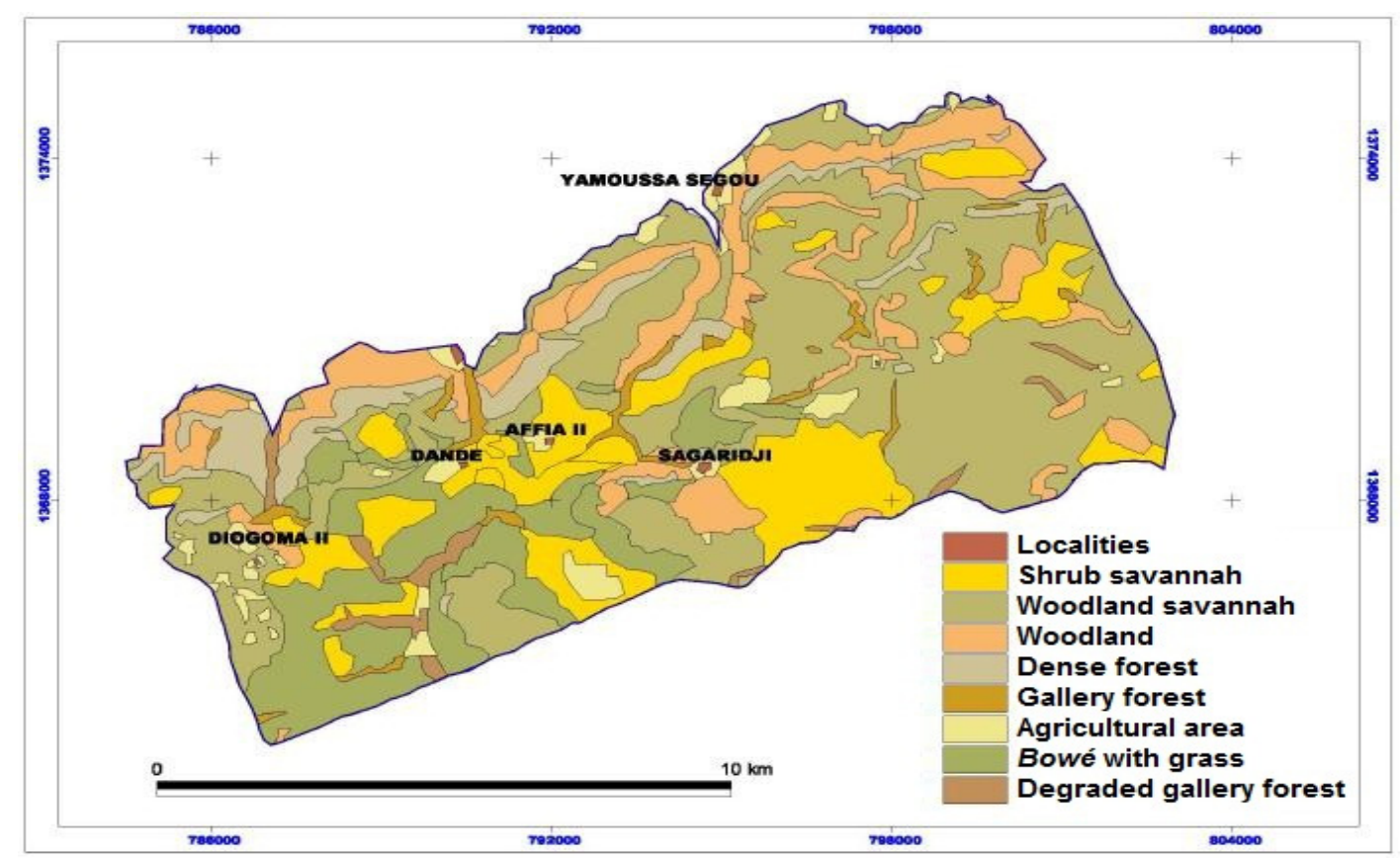

Source: Management plan of the RNCD 2012-2016, USAID/Wula Nafaa program [55].

The RNCD was established with the aim of carrying out a community-based management of its natural resources, as well as protecting the last chimpanzee population (Pan troglodytes verus) in Senegal, listed by the International Union for the Conservation of Nature (IUCN) as a worldwide endangered species with an estimated 500 individuals remaining in the country [56,57]. The presence of this species in the region represents the north-western limit of its geographical distribution and the reason why IUCN considers Dindéfélo as an important conservation area [55]. However, as in other natural areas in Africa, the conservation of chimpanzees in the RNCD faces the impacts of local people's activities, which have also a significant impact on overall biodiversity and environmental health. These mainly include deforestation, the depletion of wild edible species, fire regimes for the creation of open pastures for cattle, and pollution of watercourses [54,58,59]. Far from being ignorant of their role in environmental degradation, the population is well aware of the direct impacts of their productive activities as shown by a study carried out in the region. Villagers cited hydraulic erosion, deforestation, and wildlife disappearance as the primary natural resource management problems within their community. Other conservation challenges cited were the frequency and intensity of bush fires, the over-tapping of palm trees, and the degradation of water points [54]. Therefore, natural resources in the region of Kédougou-considered one of the last bastions of wildlife in Senegal—suffer significantly from poaching and resource overexploitation. For instance, unchecked clearing in an attempt to confront the decline of agricultural land productivity takes part in the erosion and degradation of biodiversity, substantially destroying some biotopes.

This collision of agendas generates a conflict of interests between local communities whose welfare depends on the forest goods and services, and conservationists aware of the degradation of the ecosystems. The current situation demands an extensive assessment of local sustainable biodiversity management practices in order to address the conservation challenges of this newly established reserve and to answer the threats menacing its ecological integrity. 


\subsection{Examples of Sustainable Projects in Natural Protected Areas and Future Challenges}

\subsubsection{Nurseries as an Alternative to the Unsustainable Exploitation of Forest Fruits}

The increasingly unsustainable exploitation of forest fruits in the RNCD is a source of degradation and habitat fragmentation. This is exacerbated by the fact that the diet of many animals, such as the highly endangered chimpanzee, relies on the same wild edibles collected by local communities [60]. Perhaps the most relevant example is the case of the liana Saba senegalensis (Figure 3), known also by its Wolof name madd, the fruit of which is highly appreciated by inhabitants in south-eastern Senegal and often appears in local markets in the dry season when crops are not available [61,62]. Recent improvements in transportation infrastructure between the capital city of Dakar and the region of Kédougou (including the Rural Community of Dindéfélo) have opened up opportunities for the transportation and sale of agricultural goods desired in the northern capital yet only available in the southern regions, an example of which is the madd fruit. High northern demand couples with the presence of useable transportation networks and the availability of common fruit stocks in the RNCD meaning that instead of harvesting small amounts of fruit to meet local demand, RNCD residents amass large quantities of madd in order to supply external markets [54]. It is estimated that local people who benefit from retail or wholesale of these fruits (especially women) for final marketing in big cities like Dakar get more than $50 \%$ of their annual income this way [63]. Increasing pressure on the fruit, and thus the seeds contained within it, has led to a substantial decrease in the natural regeneration of the species with subsequent negative effects on biodiversity since the chimpanzee's diet depends primarily on this fruit in the dry season and it serves as an endozoochorous seed dispersal agent, improving its fertility by the passage through the intestinal tract $[56,62]$. Based on this, it is also estimated that only local people draw approximately 75,000 fruits per month during the period of greatest abundance of $S$. senegalensis (from May to June). This amount of fruit adds up to about 4.5 million seeds that are deliberately taken out from the forest without enabling the natural reproduction of the liana, while an adult chimpanzee disperses a total of 426 seeds per day, feeding on a total of 19 fruits a day [64].

In order to make the use of this resource by local communities compatible with its preservation in the forest and its availability to chimpanzees, the viability of several courses of action has been studied in the RNCD. Firstly, methods for collecting madd fruits are usually destructive because people often cut down the liana, so that flowers which would bear the fruit the following year die. This is the easiest way for people to get it, as they only have to climb up to cut the stem, without cutting each fruit individually. In this sense, raising the population's awareness of sustainable and non-destructive practices can be very effective. Also, the zoning of the RNCD has allowed for the protection of certain areas of special importance to chimpanzees, such as the gallery forests (see Zone 1 Figure 1), which are free from any exploitation of natural resources due to their vulnerability. However, these areas are very limited for the chimpanzees in terms of space, and this is why an alternative has been proposed by the Jane Goodall Institute (JGI) Spain: to substitute the exploitation of wild fruits of madd in the RNCD with small-scale community managed tree plantations. The creation of nurseries implies a gradual reduction of the extraction of this fruit from the wild, avoiding both women collectors to access the difficult slopes of the mountains and the conflict with chimpanzees [62]. 
Figure 3. (a) Fruit of S. senegalensis; (b) S. senegalensis fruit extraction in Dindéfélo.

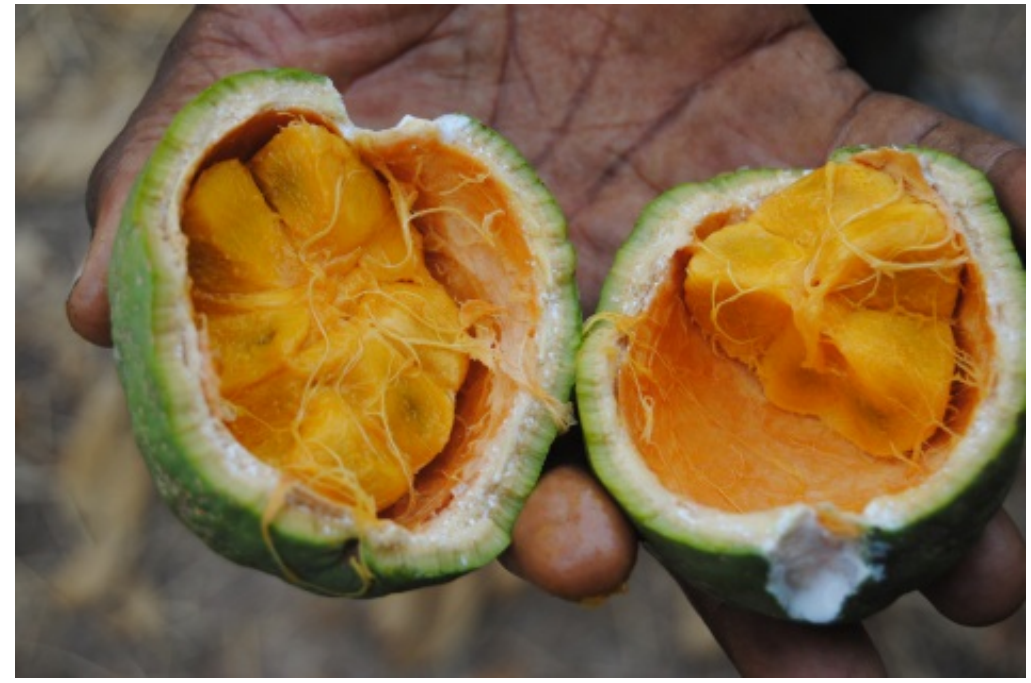

(a)

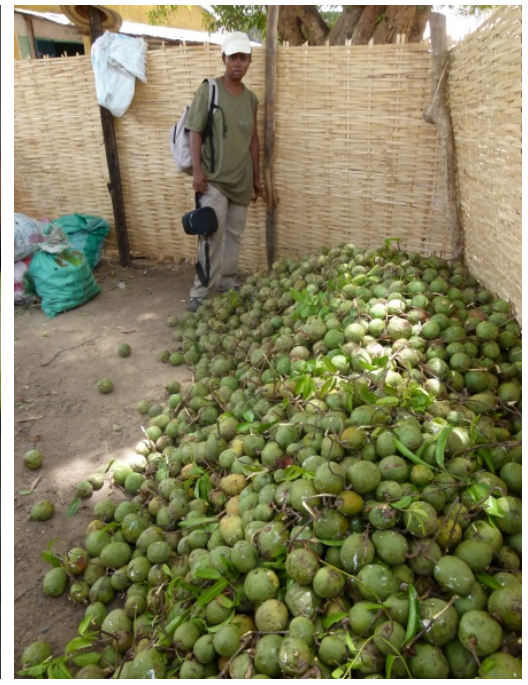

(b)

Source: JGI Spain 2011 [54,65].

Various experiments in Senegal have demonstrated the viability of small-scale S. senegalensis plantations. For instance, the USAID/Wula Nafaa program has developed successful experiences in the region of Kolda, and in the Casamance region local people from Bignona have boosted their own nursery. Thus, the proximity of the tree allows cutting the fruit in its base, so that the liana is not damaged. The infrastructure only requires the installation of a supporting structure upon which the liana grows. In addition to this, local people work through management committees, and only the creation of a group responsible for the task is needed. Perhaps the main limitation of this alternative is the time that it takes for the nursery to be productive, since $S$. senegalensis begins to bear fruit around 3-4 years after its plantation [65]. Therefore, it is very important during this period to raise awareness through sensitization activities designed to promote sustainable harvest practices. In the town of Dindéfélo, the University of Alicante and the JGI Spain have been responsible for supporting the nursery since its creation in the summer of 2012. As for the technical assistance, volunteers of the JGI Spain have been responsible for the training, although the collaboration of the University of Alicante, the University Cheikh Anta Diop in Dakar, and the USAID/Wula Nafaa program have been essential for technical issues. In early June 2012 surveys were conducted in all the villages of the RNCD, both to collectors and trade unions (formed by a committee which manages the sale of $S$. senegalensis) about the exploitation of the fruit in order to see the extraction methods, the amount of fruit extracted, and its importance in local economy. In September 2012 S. senegalensis was transplanted to the nursery field (see Figure 4). So far the actions that have been carried out comprise the construction of a deep well and supporting structures and facilities for irrigation, the training of the women responsible for the maintenance, and planting of madd seedlings. Nowadays, the Dindéfélo Women Association, working together with the Rural Council, the JGI Spain, and the Direction des Eaux et Forets (DEF), as well as an expert from the territory of the University Cheikh Anta Diop (UCAD) in Dakar are handling the maintenance of the nursery (Figure 5). The main beneficiaries are women collectors themselves, avoiding forest collection and thus improving the conservation status of chimpanzees. 
Another small-scale plantation started in summer 2012 is that of Ségou, financed by the USAID/Wula Nafaa program [62].

Figure 4. S. senegalensis transplantation to the nursery field (September 2012).

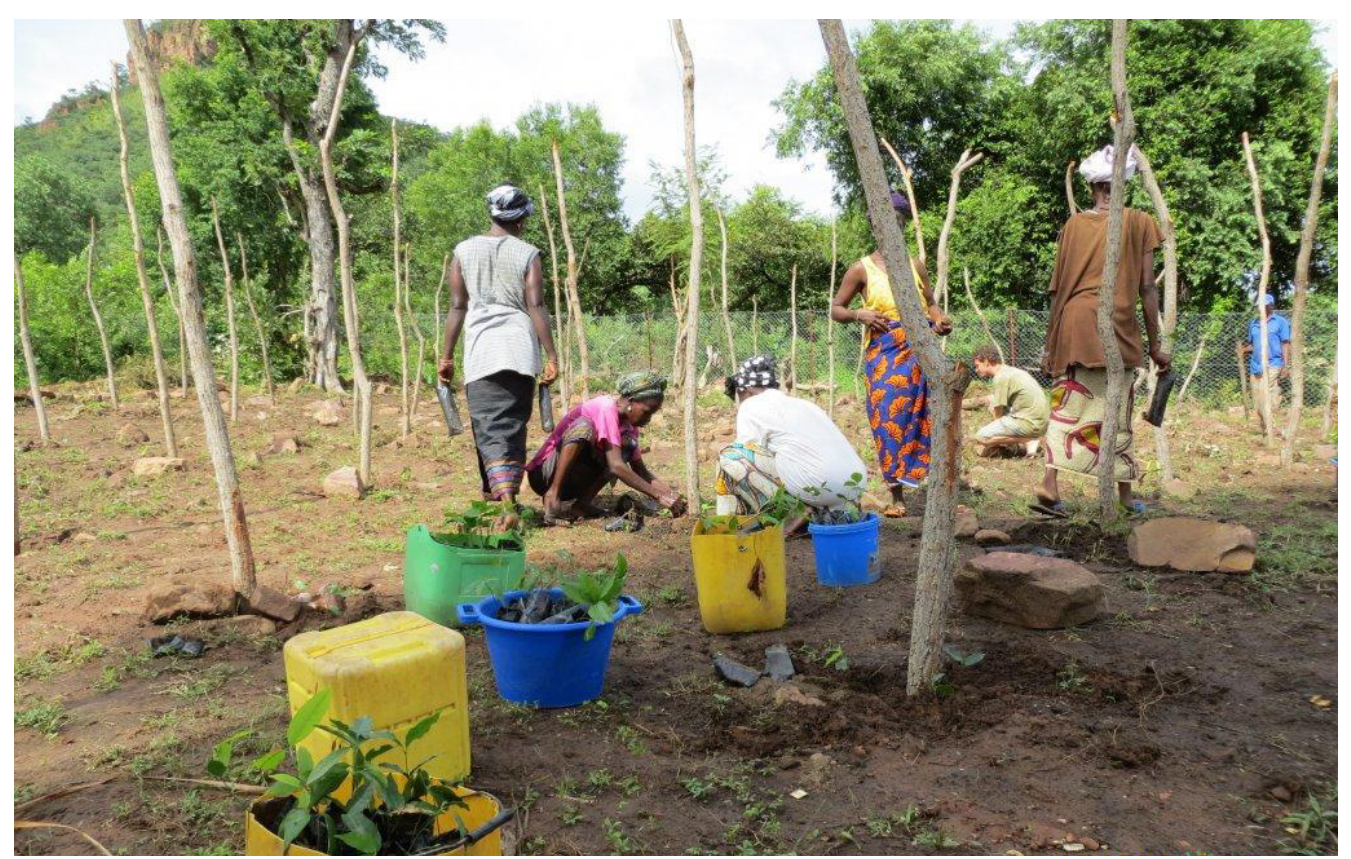

Source: JGI Spain 2012 [62].

Figure 5. Day training and work for the maintenance of the nursery (October 2012).

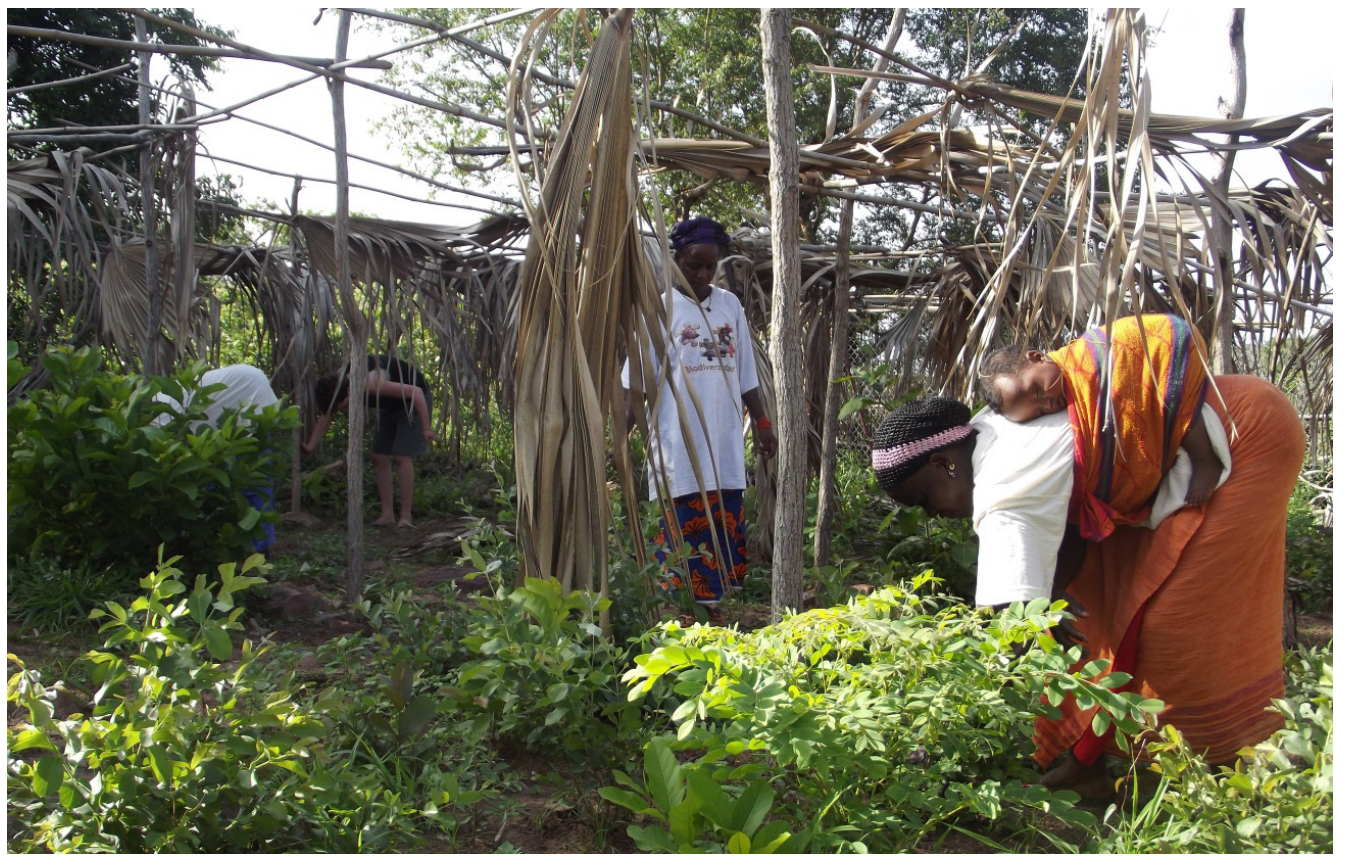

Source: JGI Spain 2012 [62].

S. senegalensis is only one example of human-wildlife resources conflict as chimps and humans share many more fruits from the forest. According to preliminary studies carried out by the JGI Spain, at least 39 forest species representing $43 \%$ of the diet of chimpanzees are shared with the local population [66]. Among these, eight are likely to be sold in both local and national markets: 
Lannea sp., Adansonia digitata, Detarium sp., Tamarindus indica, Parkia biglobosa, Ziziphus sp., Vitellaria paradoxa, Cola cordifolia [67]. Therefore, there is an urgent need to work on these species, either by propagating them in nurseries, or if this proves impossible (as with A. digitata), by defining operational zones for sustainable extraction and ensuring wildlife's access to fruit.

\subsubsection{Live Fencing: A Strategy for Sustainable Resource Conservation}

A second sustainable project active within the RNCD is the extension of live fencing. For the purposes of this paper, live fences are defined as "narrow linear strips of planted trees, generally consisting of a single row of a few densely planted species that are established and managed by farmers" [68]. Research has shown that live fencing is used throughout the world as a sustainable agriculture practice and yields numerous benefits for local populations and the environment [69-75]. Likewise, live fencing in the RNCD contributes significantly to biodiversity and forest conservation while, at the same time, having a positive financial impact on local people.

The primary implementer of live fencing technology within the RNCD is a cooperative project between the NGO Trees for the Future and the U.S. Peace Corps. The aim of the project is to extend agroforestry techniques to subsistence farmers in order to increase their food security and curb deforestation. Data comes from a study carried out amongst participants in the larger Trees for the Future-Peace Corps cooperative project, which involves communities in the entire region of Kédougou. Monthly follow-up visits were performed by program extension agents during which program participants, government officials, and prominent community leaders were interviewed regarding aspects of the program and their agricultural and land management practices. Program staff members in and around the RNCD and Peace Corps volunteers provide technical training and aid in the financing of community tree nurseries that are established and maintained by local farmers to produce saplings for the planting of live fences. Species currently being extended are Jatropha curcas, Acacia nilotica, A. mellifera, Bauhinia rufescens and Ziziphus mauritiana. These species have been chosen because they are effective barriers and animal deterrents, their seed is locally available, they are fast growing, they produce income-generating by-products, and there is local demand for their use. The Trees for the Future-Peace Corps cooperative agroforestry project has been active in the greater Kédougou Region for four years and in the Rural Community of Dindéfélo since late 2010. Due to the fact that a live fence takes two years to become fully effective, few complete examples exist in the Dindéfélo Rural Community. However, numerous examples can be found in communities throughout the Kédougou region, in Senegal, and in northern Guinea. These geographically proximate and climatically identical examples demonstrate the effectiveness of the technology and its cultural and environmental appropriateness.

At present, there are four participating communities-Dindéfélo, Ségou, Tiabécaré and Yamousa - within the RNCD, as well as one additional village, Thiangué, in the Rural Community of Dindéfélo. Until now, over 50 program participants have planted approximately 20,000 trees in live fences, and plans are to extend the program to remaining communities within two years.

The form and function of today's live fencing in the RNCD differs from its historic predecessors. Traditionally, live fencing in Dindéfélo used only $J$. curcas and had two primary functions: the cementing of land ownership claims and the controlling of human traffic in and out of a village for 
security. These practices have been documented in other areas of West Africa $[73,76]$. These traditional functions have largely fallen out of usage or been replaced by dead fences composed of woven bamboo, thorny branches, and/or tree limb posts. Today, program participants cite three main reasons for the establishment of live fences: (1) as an alternative to current fencing options for the protection of high-value and out of season agricultural products; (2) to generate income directly through the sale of live fencing by-products; and (3) for environmental conservation. An exploration of these reasons will elucidate the positive impacts of live fencing within the RNCD.

Livestock free grazing is widely practiced within the RNCD and is only restricted during the period of cereal grain production, from late-June to December. However, there are a number of profitable agricultural products that contribute significantly to villager nutrition and dietary diversity, such as manioc and garden vegetables, grown out of season and thus jeopardized by free grazing. In order to protect these plants, farmers enclose them with either a dead fence or an industrial fabricated barrier such as chain link fencings, metal posts or barbed wire. While effective, both of these fencing options pose a number of problems that can be overcome by live fencing. Dead fences degrade within one to two planting seasons due to aggressive termites, are labor intensive, and contribute significantly to deforestation as wood for their construction must be gathered from wild areas in the RNCD. Industrial fabricated barriers are financially out of reach for the majority of farmers and, being of questionable quality and subject to harsh environmental conditions, quickly rust and deteriorate. Alternatively, live fences, owing to the fact that they are composed of living plants, strengthen rather than deteriorate over time, are not subject to termite damage or rust, do not require the user to cut and gather wood, cost significantly less in terms of materials and labor than industrial barriers, and are largely permanent once established.

An important incentive to establish a live fence is income generation from fencing by-products, specifically the sale of $J$. curcas seeds and seedlings for biofuel production, artisanal soaps [77], and Z. mauritiana "jujube" fruit for consumption [78]. These extra financial incentives - absent with dead and industrial fencing-make J. curcas and Z. mauritiana the most popular live fencing species amongst participants and complement conservation. Thus, by providing villagers with proximate sources of natural products, live fencing reduces the incentive to forage for these products within the RNCD, reducing both human traffic in wild spaces and human-wildlife competition for food sources.

Live fences fill the ubiquitous demand for durable fencing materials and reduce the need to enter the forested spaces of the RNCD to clear cut for fence construction. Additionally, they are a means of adding value to a field. A typical villager land management practice is to clear-cut a field, farm there for between four and eight years, then abandon the field and begin the cycle anew. Over half of the communities in the RNCD identified a lack of cultivatable land as an environmental issue faced by their community. The presence of large numbers of livestock creates a need to split agricultural lands between pasturage and production, which leads to the overexploitation of existing farmland. Instead of allowing fallow periods or permanently abandoning depleted fields and permitting the forest and soils to naturally regenerate, farmers stay on exhausted soils and are forced to exploit increasingly large tracts of marginal lands in order to maintain previous production levels. These practices run contrary to traditional land management practices, expand the human footprint on the forest, and form a vicious cycle; as land becomes more depleted, more land must be cultivated by each farmer, causing less land to be available to all farmers and forcing the village to expand the total acreage under cultivation. 
In this way, wildlife habitats are reduced and biodiversity suffers. However, the farmer who invests in live fencing is likely to remain in his original plot and adopt traditional sustainable land use practices. The potential gains in soil fertility in a new field are offset by the ability to cultivate out of season crops and more tightly control planting regimens. Thus, abandoning a fully fenced-in field no longer becomes an economically sound decision. Throughout the region of Kédougou farmers are already practicing this technique (Figure 6).

Figure 6. Emerging live fence in the village of Ségou.

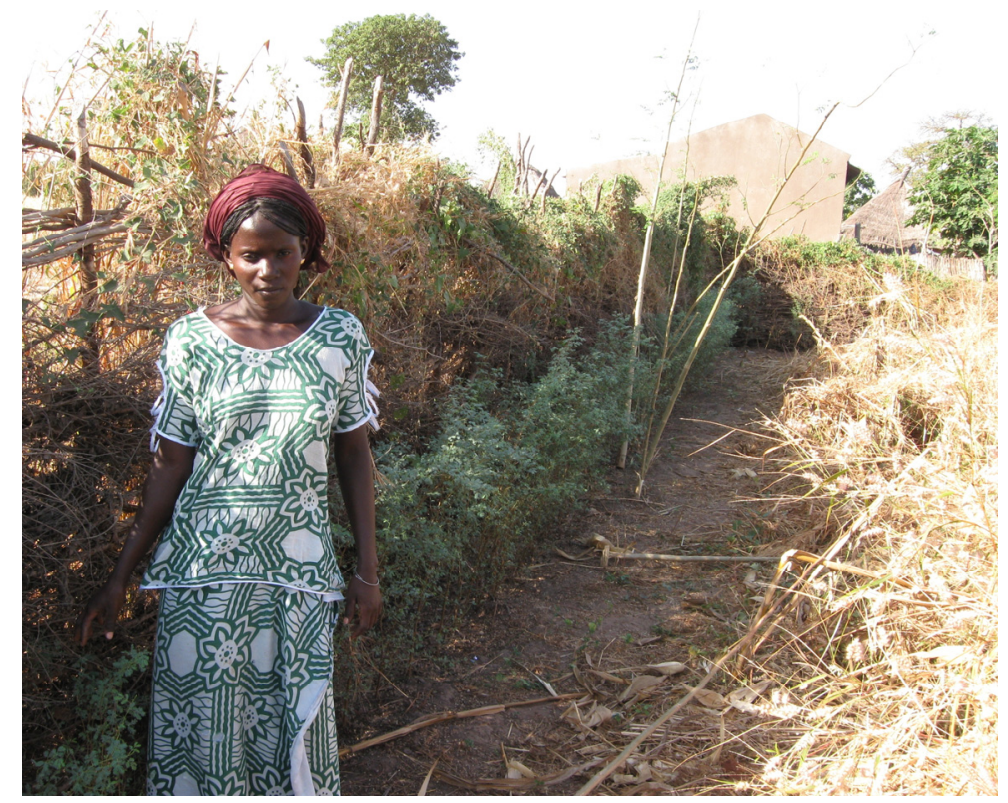

Source: Karamba Diakhaby 2011 [77,78].

Widespread adoption of live fences has the potential to preserve hectares of forest and contribute significantly to the biodiversity within the RNCD. Research suggests that live fences provide important supplementary habitat for birds [79,80] and other animal groups [68,81], and may act as movement corridors across agricultural landscapes for a variety of species [68,82], including primates [83]. While there is some risk of increasing "nuisance" wildlife incursions into farmland, the species concerned - primarily birds and small rodents - do not cause catastrophic crop damage and would be more than compensated for by gains resulting from the absence of the largest threat to cereal grains, i.e. domestic animals. Live fences in the RNCD contribute to conservation not only in what they provide in terms of habitat and movement corridors, but also in what they prevent, namely deforestation, human traffic in wild areas and human-wildlife competition while positively benefiting the villagers' economic situation in a sustainable way.

\subsubsection{Construction of Municipal Washing Facilities: An Example of Sustainable Policy-Making}

The last sustainable project explained here is the construction of a municipal washing facility at the village of Dindéfélo. One of the most relevant conflicts between humans and chimpanzees throughout the RNCD concerns encounters between these great apes and other fauna and local villagers, mostly women and young teenagers, at the water points during the dry season $[55,66]$. Preliminary studies in the reserve show that locals in six out of the 10 villages in the RNCD appear to have constant conflicts 
with chimpanzees over water resources [55]. These conflicts are not a fight over the water itself, but rather encounters involving people and wildlife attempting to access water points simultaneously. These interactions have proven dangerous, stressful, and irritating for both sides [60].

There are several sources of water in the Rural Community of Dindéfélo. In most of the rural areas located on the plateau, naturally occurring water holes are the only means available. These are often located near the smaller villages, but in some cases they are as far as 2 kilometres away. Women periodically visit the water hole in the early morning or late evening to collect water and do the laundry. After washing, women typically leave clothes to dry on nearby branches in order to avoid having to carry heavy loads of laundry back on their heads. Considering there is adequate water, women will remain near water holes for some time in order to finish their laundry. This coincides with the time when the chimpanzee and other fauna approach these points to drink [84].

Another water source in the RNCD is its many streams and rivers. These occur primarily in villages situated on the plain, such as Dindéfélo and Ségou. Those who live near a stream of river use it for bathing and laundry. Women regularly visit the streams throughout the day because they are often located in gallery forests and therefore sheltered from the sun $[85,86]$. They immerse their soiled linens in the running water and use large rocks to assist in the scrubbing process (see Figure 7). Chemical washing powders and bars as well as homemade soaps are used. After scrubbing, clothes are wrung out and left to dry in the sun or draped over bushes or branches as makeshift clothes lines [85,86].

Figure 7. Women washing clothes in the river stream of Dindéfélo.

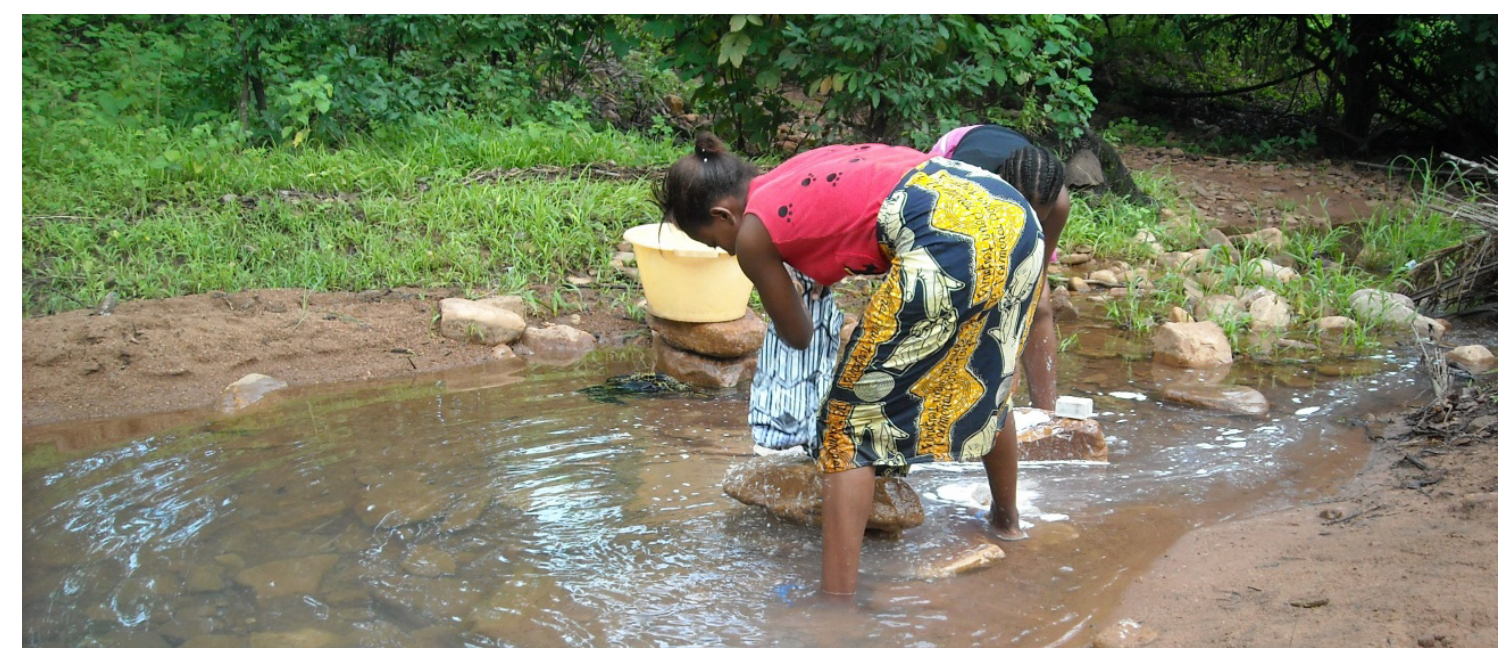

Source: JGI Spain 2010 [85,86].

The last sources of water in the RNCD are wells. Where these are present, women pump water into large buckets and carry it to their homes for domestic use. For families with access to wells, clothes are washed in large basins at their homes. However, this is a relatively rare occurrence in the RNCD as there are very few wells and those that do exist cease to have water in the dry season.

These household activities, i.e. washing clothes, dishes, and showering, as well as the fact that streams are used as latrines and as means of human waste disposal [87] have a direct impact on water quality, harm riverside flora, and pollute ground water (see Figure 8). Concretely, the use of water by local people alters the physical conditions of the riverside and impacts oxygen-consuming substances and the nutrient cycle. This entails an increase in the presence of pathogen substances dangerous for 
chimpanzees and other animals [60]. In addition to these factors, it is important to note the abject lack of proper waste disposal near water sources: The plastic bags containing chemical washing powders are left littering the riverside along with discarded clothing left hanging from the trees or on the ground becoming a solid contaminating agent. During the dry months, when food is scarce, a small number of these inedible clothing items are consumed by hungry livestock and primates, causing severe stomach obstructions and sometimes resulting in death $[55,60]$.

Figure 8. (a) Organic pollution in the washing area; (b) Clothes left drying on bushes.

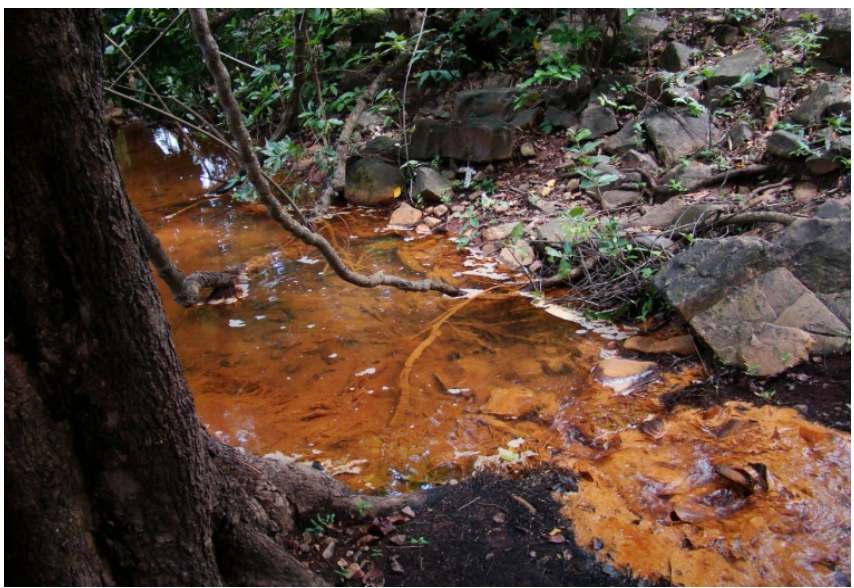

(a)

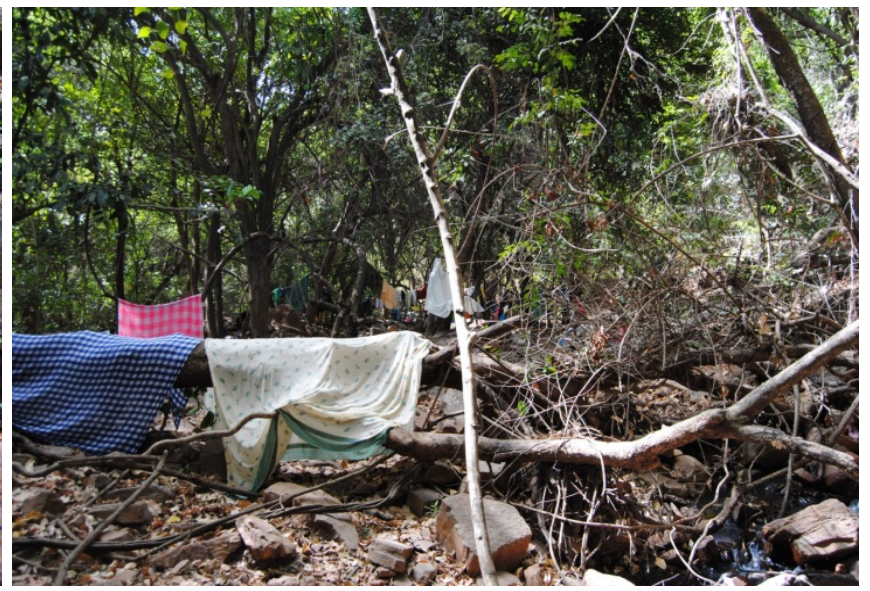

(b)

Source: JGI Spain 2010 [85,86].

The JGI Spain, which collaborates with the Rural Community of Dindéfélo for the execution of the RNCD strategic management plan, designed and constructed a municipal washing facility in Dindéfélo (Figure 9) to put an end to the increasing levels of water pollution caused by washing points in the Reserve.

Figure 9. (a) Filter system and Moringa oleifera intensive bed; (b) Local women using the new washing facilities.

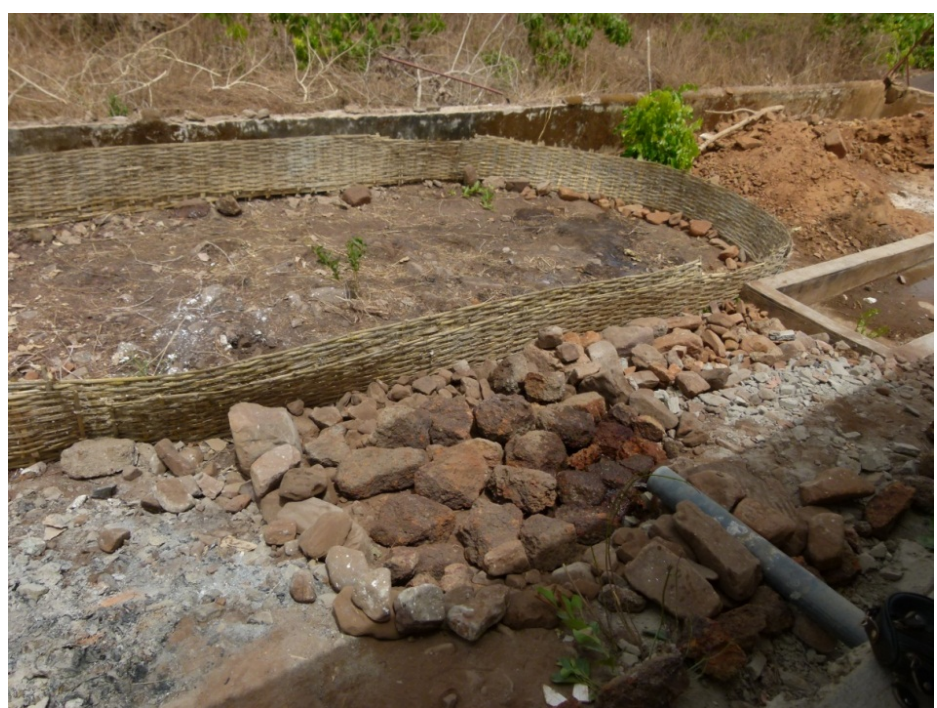

(a)

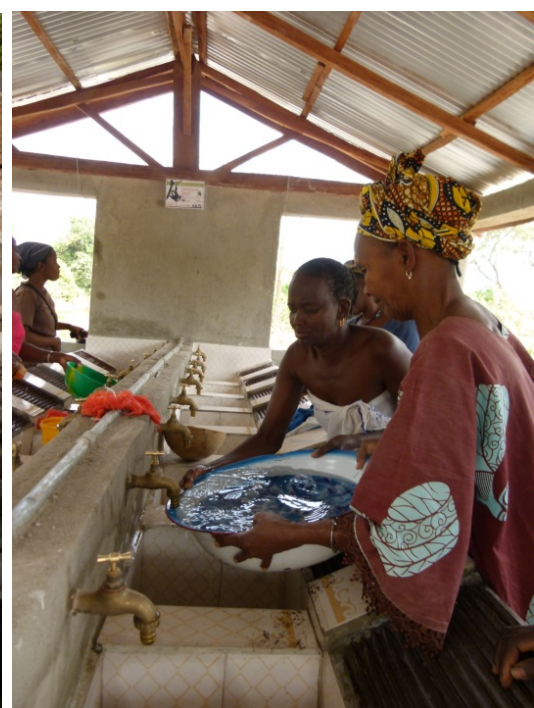

(b)

Source: JGI Spain 2012 [65,88]. 
The infrastructure was funded by the Area Metropolitana de Barcelona thanks to the elaboration and approval of the 2012-2016 RNCD's Management Plan and was, since its outset, a collective idea carried out with consensus of local people, particularly the approval of local women. This process was participatory in all phases and the feedback from potential users was collected and incorporated into the final proposal, including the location (the town center) and the favorite operating mechanism (with taps). The selection of the village of Dindéfélo as the benefactor of the installation was justified by two reasons: (1) it is the most populated village in the RNCD, with more than 1600 people [55]; and (2) the Dindéfélo stream used to conduct household activities situated near the highest waterfall in Senegal, which is important for conservation and tourism, was already severely degraded by pollution as has been recognized by the local economies. Local women were the primary benefactors of the project, but no more so than chimpanzees and other flora and fauna of the RNCD who rely on the stream as their water source.

The water quality in the streams of the RNCD is expected to improve in the long-term with the construction of the washing facility, which is maintained by the same community and where users have received the adequate training in order to minimize water pollution. This is due in large part to the installation of a gray water waste control station consisting of a filter system and Moringa oleifera intensive bed. The water evacuation system is simple yet effective and is comprised of several filter layers including carbon. Following filtration, water flows into a dense plantation of M. oleifera. This species is used by local people to purify ground water by making use of a phytoremediation process; its roots have an essential oil that can render gray water potable $[65,88]$. The plant is also used for erosion control and live fencing [88]. The installation of the washing facility solid waste management plan focused especially on plastic bags, as well as an environmental education program in an effort to holistically address the pollution problems faced by the Dindéfélo community. It is important to note that the new washing facility also provides additional advantages to the users as for instance shade or privacy, as well as alternative uses such as showering or personal hygiene.

\section{Concluding Remarks}

The conservation model of the RNCD began as an experiment to enhance the conservation of African chimpanzees, which are highly endangered, from a community-based perspective. Since its creation in 2010, it has proved that including local knowledge and people's perceptions in the design and implementation of management plans of Natural Protected Areas gives conservation schemes a better chance of success. However, any management of natural resources in Community Nature Reserves must be carried out under the framework of sustainable development. Much of the narrative on community conservation coincides with putting the sustainable use of natural resources on top of the strategies for achieving poverty reduction and social justice, but it generally lacks concrete examples on how to deal with sustainability at a practical level. Although sustainable development is always recognized as a priority for local stakeholders and conservation agents in protected areas, there is a reduced body of literature on sustainable strategy in Natural Protected Areas and examples on how to cope with it. In this sense, the present work is somehow unique as it provides a reliable picture of a particular framework to develop sustainable projects that are valuable from the perspective of biodiversity conservation. The three different examples shown in this article illustrate different paths 
by which conservation goals can be achieved through the sustainable use of natural resources, mainly forest resources, improving socioeconomic development and human well-being. Small-scale plantations of $S$. senegalensis avoid unsustainable harvest practices and reduce the conflict in particular between humans and chimps during the dry season, while at the same time allowing its preservation in the forest. Live fencing is shown as an alternative to current fencing options for the protection of high-value and out of season agricultural products, to generate income directly through the sale of live fencing by-products, but also contributing to conservation in terms of habitat provision and movement corridors. Therefore, they prevent deforestation, human traffic in wild areas and human-wildlife competition while positively benefiting the villagers' economic situation in a sustainable way. Finally, the municipal washing facility constructed in the village of Dindéfélo has put an end to the increasing levels of water pollution caused by washing points in the Reserve, ameliorating the quality of life of chimpanzees and other flora and fauna of the RNCD who rely on the stream as their water resource. For all the reasons that have been exposed here, these projects meet the criteria of being ecologically sustainable, economically viable and socially fair.

In a continent like Africa, where both human development and conservation of natural areas are urgently needed, initiatives like the ones carried out in the RNCD emerge as a viable way towards sustainable resource conservation.

\section{Acknowledgments}

This paper has benefited from discussions with Victoria Reyes-García, who has been closely involved throughout the process of manuscript preparation. Our gratitude also goes to the Institute of Environmental Sciences and Technology (Institut de Ciència i Tecnologia Ambientals, ICTA), and the JGI Spain (Instituto Jane Goodall España, IJGE), for all their continued support and commitment during the writing of this article. Special thanks also goes to the different entities and organizations supporting the projects carried out at the RNCD: U.S. Peace Corps, Trees for the Future, Area Metropolitana de Barcelona and Fundación Biodiversidad.

\section{Conflict of Interest}

The authors declare no conflict of interest.

\section{References}

1. Simsik, M.J. The political ecology of biodiversity conservation on the Malagasy Highlands. Geo. J. Lib. 2002, 58, 233-242.

2. Borghesio, L. Biodiversity erosion in the Vadua Nature Reserve (Turin, Piedmont, NW Italy). Rivista Piemontese di Storia Naturale 2004, 25, 371-389.

3. Dawson, T.P.; Jackson, S.T.; House, J.I.; Prentice, I.C.; Mace, G.M. Beyond predictions: Biodiversity conservation in a changing climate. Science 2011, 332, 53-58.

4. Davis, S.D.; Droop, S.J.M.; Gregerson, P.; Henson, L.; Leon, C.J., Villa-Lobos, J.L.; Synge, H.; Zantovska, J. Plants in Danger. What Do We Know?, 1st ed.; IUCN: Gland, Switzerland, 1986. 
5. Pimm, S.L.; Russell, G.J.; Gittleman, J.L.; Brooks, T.M. The future of biodiversity. Science 1995, 269, 347-350.

6. Akeroyd, J. A rational look at extinction. Plant Talk 2002, 28, 35-37.

7. Vié, J.-C.; Hilton-Taylor, C.; Stuart, S.N. Wildlife in a Changing World-An Analysis of the 2008 IUCN Red List of Threatened Species, 1st ed.; IUCN: Gland, Switzerland, 2009.

8. Brummit, N.; Bachman, S. Plants under Pressure, a Global Assessment. The first Report of the IUCN Sampled Red List Index for Plants, 1st ed.; Royal Botanic Gardens: Kew, UK, 2010.

9. Daily, G.C. Nature's Services: Societal Dependence on Natural Ecosystems, 1st ed.; Island Press: Washington, D.C., USA, 1997.

10. Millennium Ecosystem Assessment. Ecosystems and Human Well-Being: Synthesis, 1st ed.; Island Press: Washington, D.C., USA, 2005.

11. Bandeira, S.O.; Albano, G.; Barbosa, F.M. Diversity and Uses of Plant Species in Goba, Lebombo Mountains, Mozambique, with Emphasis on Trees and Shrubs. In African Plants: Biodiversity, Taxonomy and Uses, 1st ed.; Timberlake, J., Kativu, S., Eds.; Royal Botanic Gardens: Kew, UK, 1999.

12. van Wyk, B.-E.; Gericke, N. People's Plants: A Guide to Useful Plants of Southern Africa, 1st ed.; Briza Publications: Pretoria, South Africa, 2000.

13. World Health Organization (WHO). World Health Organization Traditional Medicine Strategy 2002-2005, 1st ed.; WHO: Geneva, Switzerland, 2002.

14. Khumbongmayum, A.D.; Khan, M.L.; Tripathi, R.S. Sacred groves of Manipur-Ideal centres for biodiversity conservation. Curr. Sci. India 2004, 87, 430-433.

15. Antwhal, A.; Gupta, N.; Sharma, A.; Anthwal, S.; Kim, K.-H. Conserving biodiversity through traditional beliefs in sacred groves in Uttarakhand Himalaya, India. Resour. Conserv. Recy. 2010, 54, 962-971.

16. Okafor, J.C. Amélioration des essences forestières donnant des produits comestibles. Unasylva 1991, 42, 1991-1992.

17. Savy, M. Diversité, variété alimentaire et état nutritionnel des mères de jeunes enfants en milieu rural défavorisé. MSc Dissertation, Ouagadougou University, Burkina Faso, 2002.

18. Soubeiga, K.J. Analyse de la demande des produits forestiers non ligneux dans l'alimentation des ménages ruraux: Cas des départements de Bondoukuy (Mouhoun) et Niandialia (Boulkiemdé). BSc Dissertation, Université Polytechnique de Bobo-Dioulasso, Burkina Faso, 2004.

19. Codija, J.T.C.; Assogbadjo, A.E.; Ekue, M.R.M. Diversité et valorisation au niveau local des ressources végétales forestières alimentaires du Bénin. Cahiers agricultures 2003, 12, 321-331.

20. Ouédraogo, A.; Thiombiano, A.; Hahn-Hadjali, K.; Guinko, S. Diagnostic de l'état de dégradation des peuplements de quatre espèces ligneuses en zone soudanienne du Burkina Faso. Sécheresse 2006, 17, 485-491.

21. Thiombiano, D.N.E.; Lamien, N.; Dibong, S.D.; Boussim, I.J. État des peuplement des espèces ligneuses de soudure des communes rurales de Pobé-Mengao et de Nobéré (Burkina Faso). J. Anim. Plant. Sci. 2010, 9, 1104-1116.

22. Shankar, U.; Hedge, R.; Bawa, K.S. Extraction of non-timber forest products in the forests of Biligiri Rangan Hills, India. 6. Fuelwood pressure and management options. Econ. Bot. 1998, 52, 320-336. 
23. Dalle, S.P.; de Blois, S. Shorter fallow cycles affect the availability of non-crop plant resources in a shifting cultivation system. Ecol. Soc. 2006, 11. Available online: http://www.ecologyand society.org/vol11/iss2/art2/ (accessed on 8 June 2012).

24. Guariguata, M.R.; Cronkleton, P.; Shanley, P.; Taylor, P.L. The compatibility of timber and non-timber forest product extraction and management. Forest Ecol. Manag. 2008, 256, 1477-1481.

25. Meffe, G.K.; Carroll, C.R. Principles of Conservation Biology, 1st ed.; Sinauer Associates: Sunderland, CA, USA, 1994.

26. Lykke, A.M. Local perceptions of vegetation change and priorities for conservation of woody-savanna vegetation in Senegal. J. Environ. Manage. 2000, 59, 107-120.

27. Salafsky, N.; Cauley, H.; Balachander, G.; Cordes, B.; Parks, J.; Margoluis, C.; Bhatt, S.; Encarnacion, C.; Russel, D.; Margoluis, R. A systematic test of an enterprise strategy for community-based biodiversity conservation. Conserv. Biol. 2001, 15, 1585-1595.

28. Toledo, V.M. Biodiversity and Indigenous Peoples. In Encyclopedia of Biodiversity, 2nd ed.; Levin, S.A., Ed.; Academic Press: Utah, USA, 2000.

29. Alcorn, J. Indigenous peoples and conservation. Conserv. Biol. 1993, 7, 424-426.

30. Jusoff, K.; Majid, N.M. Integrating needs of the local community to conserve forest biodiversity in the state of Kelantan. Biodivers. Conserv. 1995, 4, 108-114.

31. Berkes, F. Community-based conservation in a globalized world. P. Natl. Acad. Sci. USA 2007, 104, 15188-15193.

32. Porter-Bolland, L.; Ellis, E.A.; Guariguata, M.R.; Ruiz-Mallén, I.; Negrete-Yankelevich, S.; Reyes-García, V. Community managed forests and forest protected areas: An assessment of their conservation effectiveness across the tropics. Forest Ecol. Manag. 2012, 268, 6-17.

33. Adams, W.M.; Aveling, R.; Brockington, D.; Dickson, B.; Elliott, J.; Hutton, J.; Roe, D.; Vira, B.; Wolmer, W. Biodiversity conservation and the eradication of poverty. Science 2004, 306, 1146-1149.

34. Chan, K.M.A.; Pringle, R.M.; Ranganathan, J.; Boggs, C.L.; Chan, Y.L.; Ehrlich, P.R.; Haff, P.K.; Heller, N.E.; Al-Khafaji, K.; Macmynowski, D.P. When agendas collide: Human welfare and biological conservation. Conserv. Biol. 2007, 21, 59-68.

35. McNeely, J.A.; Faith, D.P.; Albers, H.J. Biodiversity, Chapter 5 in Policy Responses. In Part III: Millennium Ecosystem Assessment, 1st ed.; Chopra, K., Leemans, R., Eds.; Island Press: Washington, D.C., USA, 2005.

36. Cranford, M.; Mourato, S. Community conservation and a two-stage approach to payments for ecosystem services. Ecol. Econ. 2011, 71, 89-98.

37. Engel, S.; Pagiola, S.; Wunder, S. Designing payments for environmental services in theory and practice: An overview of the issues. Ecol. Econ. 2008, 65, 663-674.

38. O'Connell-Rodwell, C.E.; Rodwell, T.; Rice, M.; Hart, L.A. Living with the modern conservation paradigm: Can agricultural communities co-exist with elephants? A five-year case study in East Caprivi, Namibia. Biol. Conserv. 2000, 93, 381-391.

39. King, B.H. Conservation and community in the new South Africa: A case study of the Mahushe Shongwe Game Reserve. Geoforum 2007, 38, 207-219. 
40. Sanderson, S.E.; Redford, K.H. Contested relationships between biodiversity conservation and poverty alleviation. Oryx 2003, 37, 1-2.

41. Fisher, B.; Christopher, T. Poverty and biodiversity: measuring the overlap of human poverty and the biodiversity hotspots. Ecol. Econ. 2007, 62, 93-101.

42. Fortwangler, C.L. Social Justice Biodiversity Conservation and Protected Areas. In Contested Nature: Promoting International Biodiversity with Social Justice in the Twenty-First Century, 1st ed.; Brechin, S.R., Wilshusen, P.R., Fortwangler, C.L., West, P.C., Eds.; State University of New York Press: Albany, NY, USA, 2003; pp. 25-40.

43. Wells, M. Biodiversity conservation, affluence and poverty: Mismatched costs and benefits and efforts to remedy them. Ambio 1992, 21, 237-243.

44. Roe, D.; Elliot, J. Poverty reduction and biodiversity conservation: Rebuilding the bridges. Oryx 2004, 38, 137-139.

45. West, P.; Igoe, J.; Brockington, D. Parks and peoples: The social impact of protected areas. Annu. Rev. Anthropol. 2006, 35, 251-277.

46. Sudtongkong, C.; Webb, E.L. Outcomes of state vs. community-based mangrove management in southern Thailand. Ecol. Soc. 2008, 13, 27.

47. IUCN (International Union for Conservation of Nature). Beyond Rhetoric: Putting Conservation to Work for the Poor, 1st ed.; IUCN: Gland, Switzerland, 2002.

48. World Bank. The World Bank Annual Report 2011, 1st ed.; World Bank: Washington, D.C., USA, 2011.

49. Hartup, B.K. Community conservation in Belize: Demography, resource use, and attitudes of participating landowners. Biol. Conserv. 1994, 69, 235-241.

50. Hamilton, R.J.; Potuku, T.; Montambault, J.R. Community-based conservation results in the recovery of reef fish spawning aggregations in the Coral Triangle. Biol. Conserv. 2011, 144, $1850-1858$.

51. Guzmán, F. Environmental issues and the role of international Official Development Assistance in Senegal. MSc Dissertation, Instituto Universitario de Desarrollo y Cooperación de la Universidad Complutense de Madrid (IUDC-UCM), Spain, 2007.

52. Caudill, H.; Besseko-Diallo, O. Mido Waawi Pular! Learner's Guide to Pular (Fuuta Jallon), 2nd ed.; Peace Corps: Conakry, Guinea, 2000.

53. Olson, D.M.; Dinerstein, E.; Wikramanayake, E.D.; Burgess, N.D.; Powell, G.V.N.; Underwood, E.C.; D’Amico, J.A.; Itoua, I.; Strand, H.E.; Morrison, J.C.; et al. Terrestrial ecoregions of the world: A new map of life on Earth. BioScience 2001, 51, 933-938.

54. USAID (United States Agency for International Development). Étude Socio-Economiques de Dindéfélo, 1st ed.; Programme USAID/Wula Nafaa: Kédougou, Senegal, 2011.

55. Réserve Naturelle Communautaire de Dindéfélo, RNCD. Plan de Gestion de la Réserve Naturelle Communautaire de Dindéfélo, 1st ed.; Institut Jane Goodall Espagne et Programme USAID/Wula Nafaa: Dindéfélo, Senegal, 2011.

56. Carter, J.; Ndiaye, S.; Pruetz, J.; McGrew, W.C. Senegal. In West African Chimpanzees. Status Survey and Conservation Action Plan, 1st ed.; Kormos, R., Boesch, C., Bakarr, M.I., Butynski, T., Eds.; IUCN: Gland, Switzerland, 2003. 
57. Pruetz, J.D.; Marchant, L.M.; Amo, J.; McGrew, W.C. Survey of savanna chimpanzees (Pan troglodytes verus) in Southeastern Sénégal. Am. J. Primatol. 2002, 58, 35-43.

58. Newmark, W.D.; Hough, J.L. Conserving wildlife in Africa: Integrated conservation and development projects and beyond. BioScience 2000, 50, 585-592.

59. Struhsaker, T.T.; Struhsaker, P.J.; Siex, K.S. Conserving Africa's rain forests: Problems in protected areas and possible solutions. Biol. Conserv. 2005, 123, 45-54.

60. Hockings, K.; Humle, T. Best Practice Guidelines for the Prevention and Mitigation of Conflict between Humans and Great Apes, 1st ed.; IUCN/SSC Primate Specialist Group (PSG): Gland, Switzerland, 2009.

61. Burkill, H.M. The Useful Plants of West Tropical Africa, 2nd ed.; Royal Botanic Gardens: Kew, UK, 1994; Volume 2.

62. López, G.M. Creación de un Vivero de Saba senegalensis Gestionado por la Asociación de Mujeres de Dindéfélo dentro del Programa de Conservación del Chimpancé Pan troglodytes verus en Senegal y Desarrollo del Ecoturismo Costenible; Project report; University of Alicante: Alicante, Spain, 2011.

63. Knutsen, P.G. Threatened existence: Saba senegalensis in southeastern Senegal. MSc Dissertation, Iowa State University, IA, USA, 2003.

64. Waller, M. Competition between chimpanzees and humans over fruit of Saba senegalensis in southeastern Senegal. MSc Dissertation, Iowa State University, IA, USA, 2005.

65. Arbonnier, M. Arbres, Arbustes et Lianes des Zones Sèches d'Afrique de l'Ouest, 2nd ed.; CIRAD: Montpellier, France, 2002.

66. Pacheco, L. Table of Wild Plants Eaten by Chimpanzees at RNCD, 1st ed.; RNCD: Kédougou, Senegal, 2011.

67. Centre de Suivi Écologique (CSE). Étude Préliminaire: Synthèse des Travaux de Recherche et d'Études sur l'Évaluation Économique ou la Contribution dans la Satisfaction des Besoins des Ménages des Ressources Sauvages au Sénégal, 1st ed.; Ministère de 1'Environnement et de la Protection de la Nature: Dakar, Senegal, 2005.

68. Chacón, M.; Harvey, C.A. Live fences and landscape connectivity in a neotropical agricultural landscape. Agr. Syst. 2006, 68, 15-26.

69. Rocheleau, D.; Weber, F.; Field, A. Agroforestry in Dry-Land Africa, 1st ed.; ICRAF: Nairobi, Kenya, 1988.

70. Budowski, G.; Russo, R.O. Live fence posts in Costa Rica: A compilation of the farmer's beliefs and technologies. J. Sustain. Ag. 1993, 3, 65-87.

71. Gautier, D. The pole cutting practice in the Bamileke country Western Cameroon. Agroforest. Syst. 1995, 31, 21-37.

72. Villanueva, J.F.; Sánchez, R.; Carrete, F.O.; Mena, L. Establishment of different tree species for live fences on the Nayarit coast. Técnica Pecuaria en México 1996, 34, 64-70.

73. Ayuk, E.T. Adoption of agroforestry technology: The case of live hedges in the central plateau of Burkina Faso. Agr. Syst. 1997, 54, 189-206. 
74. Oteng'i, S.B.B.; Stigter, C.J.; Ng'ang'a, J.K.; Mungai, D.N. Wind protection in a hedged agroforestry system in semiarid Kenya. Agr. Syst. 2000, 50, 137-156.

75. Choudhury, P.R.; Rai, P.; Patnaik, U.S.; Sitaram, R. Live fencing practices in the tribal dominated eastern ghats of India. Agr. Syst. 2004, 63, 111-123.

76. Levasseur, V.; Olivier, A.; Kaya, B.; Franzel, S. L'Adoption des Haies Vives d'Épineux par les Paysans du Cercle de Ségou au Mali: Le Signe d'Une Société en Mutation? In 2ème Atelier Régional Sur les Aspects Socio-Économiques de l'Agroforesterie au Sahel, Bamako, Mali, 4-6 March 2002.

77. Tigere, T.A.; Gatsi, T.C.; Mudita, I.I.; Chikuvire, T.J.; Thamangani, S.; Mavunganidze, Z. Potential of Jatropha curcas in improving smallholder farmers' livelihoods in Zimbabwe: An exploratory study of Makosa Ward, Mutoko District. J. Sustain. Dev. Af. 2006, 8, 1-9.

78. Arndt, S.K.; Clifford, S.C.; Popp, M. Ziziphus: A Multipurpose Fruit Tree in Arid Regions. In Sustainable Land-Use in Deserts, 1st ed.; Brecke, S.W., Veste, M., Wucherer, W., Eds.; Springer: New York, NY, USA, 2001.

79. Merijin, B.; Máxime, F.; Rasmus, N.; Brátice, R.; Marta, Z. Why hedgerows? The value of hedgerows for nature and society, and for conventional and organic farmers. Ecological Agriculture University of Copenhagen. Available online: http://www.course info.life.ku.dk/Kurser/LPLF10355/presentation/ /media/Kurser/IJV/250069/biodiversity2004.pdf .ashx (accessed on 10 July 2012).

80. Pulido, P.; Renjifo, L.M. Live fences as tools for biodiversity conservation: A study case with birds and plants. Agr. Syst. 2011, 81, 15-30.

81. Estrada, A.; Cammarano, P.L.; Coates, R. Bird species richness in vegetation fences and in strips of residual rain forest vegetation at Los Tuxtlas, Mexico. Biodivers. Conserv. 2000, 9, 1399-1416.

82. Harvey, C.A.; Villanueva, C.; Villacís, J.; Chacón, M.; Muñoz, D.; López, M.; Ibrahim, M.; Gómez, R.; Taylor, R.; Martínez, J.; et al. Contribution of live fences to the ecological integrity of agricultural landscapes in Central America. Agr. Ecosys.t Environ. 2005, 111, 200-230.

83. Estrada, A.; Saenz, J.; Harvey, C.; Naranjo, E.; Muñoz, D.; Rosales, M. Primates in Agroecosystems: Conservation Value of Some Agricultural Practices in Mesoamerican Landscapes. In Study of Mesoamerican Primates: Distribution, Ecology, Behavior and Conservation, 1st ed.; Estrada, A., Garber, P., Pavelka, M., Eds.; Kluwer Academic Publisher: New York, NY, USA, 2006.

84. Tonooka, R. Leaf-folding behavior for drinking water by wild chimpanzees (Pan troglodytes verus) at Bossou, Guinea. Anim. Cogn. 2001, 4, 325-334.

85. Woodfork, J.C. Culture and Customs of the Central African Republic, 1st ed.; Greenwood Press: London, UK, 2006.

86. Skjønsberg, E. Change in an African Village. Kefa Speaks, 1st ed.; Kumarian Press: Connecticut, CT, USA, 1989.

87. Raddad, K. Water Resources and Use. In Workshop on Environmental Statistics, Dakar, Senegal, 28 February-4 March 2005; University of Dakar: Dakar, Senegal, 2005. 
88. Thies, E. Principaux Ligneux Agro-Forestiers de la Guinée. Zone de Transition, 1st ed.; Deutsche Geessellschaft für Technische Zusammenarbeit: Berlin, Germany, 1995.

(C) 2012 by the authors; licensee MDPI, Basel, Switzerland. This article is an open access article distributed under the terms and conditions of the Creative Commons Attribution license (http://creativecommons.org/licenses/by/3.0/). 